\title{
Carbamazepine distinguishes between adenosine receptors that mediate different second messenger responses
}

\author{
Dietrich Van Calker ', Raimund Steber ', Karl-Norbert Klotz ${ }^{2 *}$ and Waldemar Greil ${ }^{1}$ \\ 'Psychiatric Hospital. Unicersisy of Munich. D-8000 Munich 2. F.R.G.; and 'Pharmicological Insiltute. Linicersity of Heidelberg, \\ D-69CO Hoidelberg. F.R.G.
}

Received 23 August 1990, revised MS received 27 November 1990, accepted 18 December 1990

\begin{abstract}
The mechanism of the therapeutic and prophylactic effects of carbamazepine (CBZ) in affective psychoses is unknown but may in part be related to the potent competitive interaction of $\mathrm{CBZ}$ with adenosine-binding sites in the brain. The anticonvulsait and sedative properties of CBZ are reminiscent of the effects evoked by adenosine-agonists and contrast sharply with the opposite actions of adenosine-antagonists like caffeine. However, indirect evidence suggests an antagonist- rather than an agonist-like activity of $\mathrm{CBZ}$ at adenosine-receptors. We have used various model systems, in which adenosine receptor subtypes mediate different second messenger-responses, to investigate this apparent paradox, CBZ was found to antagonize the $\mathrm{A}_{i}$-receptor-mediated inhibition of cyclic AMP accumulation in cultured astroblasts and in $\mathrm{GH}_{3}$-cells. Furthermore, $\mathrm{CBZ}$ also inhibits the adenosine-induced increase in the level of cyclic :MP in cultured astroblasts, which is mediated by low-affinity $A_{2 b}$-receptors. In contrast, $\mathrm{CBZ}$ does not block the inhibition elicited by adenosine-agonists of the agonist-induced increased formation of inositolphosphates in human neutrophils, which is mediated by high-affinity $A_{2 a}$-receptors. The specific antagonism by $C B Z$ of $A_{1}$ but not of high-affinity $A_{23}$-receptors was further supported by binding experiments using rat brain membranes. These results suggest that the paradox of CBZ's antagonistic effects at adenosine-receptors might be at least partially reconciled by a selective antagonistic action of $C B Z$ at $A_{1}$ receptors but not at high-affinity $A_{20}$-receptors.
\end{abstract}

Adenosine receptors; Cyclic AMP; Inositol phosphates; Astroglia; $\mathrm{GH}_{3}$-cells: Neutrophils (human)

\section{Introduction}

The tricyclic iminostilbene-derivative carbamazepine (CBZ) is well known for its anticonvulsive properties and its efficacy in the treatment of parcxysmal pain syndromes. Over the last few years evidence has accumulated that $\mathrm{CBZ}$ is also effective in the treatment of acute mania and as a prophylactic agent in manic-depressive illness (for recent reviews see Elphick. 1988; Post, 1987, 1990; Schmidt and Greil, 1987). The anticonvulsive properties of $\mathrm{CBZ}$ may predominantly be due to allosteric blockade of voltage-sensitive $\mathrm{Na}^{+}$. channels (for review see Catteral, 1987), while GABA mechanisms may account for its antinociceptive properties (for review see Post. 1990). Among the various other potential mechanisms that may be responsible for CBZ's efficacy in affective psychoses (for review see Elphick. 1988; Post, 1987, 1990) its interaction with adenosine

\footnotetext{
- Present address: Department of Chemistry, Montana State University, Gaines Hall, Bozeman. MT 59717, U.S.A.
}

Correspondence to: Dr. D. Van Calker, Psychiatrische Klinik der Universităt München. Nussbaumstrasse 7, D-8000 Munich 2. F.R.G. binding sites in the brain has received special attention (Fujiwara et al.. 1987: Gasser et al., 1988; Marangos et al.. 1985, 1987a,b,c; Phillis, 1984: Skerritt et al., 1983a, b; Weir et al.. 1984). The clinical properties of CBZ are reminiscent of the anticonvulsive. sedative and anxiolytic effects of adenosine-agonists and contrast sharply to the opposite actions of adenosine-antagonists like caffeine (for review see Bridges et al.. 1988). Although this would suggest that $C B Z$ might have adenosineagonist properties, there is substantial indirect evidence to the contrary. Chronic administration of $\mathrm{CBZ}$ to rats, like that of caffeine, results in persistent up-regulation of adenosine binding sites in the brain (Daval et al., 1989; Marangos et al., 1985, 1987b). In addition. CBZ's effects on adenosine binding sites are affected by temperature and guanyl nucleotides in a manner typical for adenosine antagonists (Marangos et al.. 1987b).

Possible mixed agonist-antagonist properties of $\mathrm{CBZ}$ and/or differential effects on adenosine receptor subtypes have been suggested to account for this paradox (Post, 1987). Adenosine receptors have been originally distinguished as $A_{1}$-receptors that inhibit and $A_{2}$-receptors that activate adenylate cyclase (Londos et al., 1980; 
Van Calker et al., 1978, 1979). Based on more recent evidence indicating that adenosine receptor-regulated events might in several cases also be independent of cyclic AMP, adenosine receptors are now classified according to the struclure-activity-relationship (SAR) of various adenosine analogues (Hamprecht and Van Calker, 1985). In addition, $A_{2}$-receptors could be further subdivided into high-affinity $A_{2 a}$-receptors and low-affinity $A_{2 b}$-receptors, which apparently also show differences in the SAR of newly developed adenosineanalogues (Bruns et al., 1987).

To assess directly the question of possible agonist or antagonist actions of $\mathrm{CBZ}$ at adenosine receptor subtypes, we have investigated the effects of CBZ in cellular model systems, in which adenosine receptor subtypes mediate differen: second messenger-responses. The results indicate that $C B Z$ antagonizes the effects of adenosine at $A_{1}$-receptors but not at $A_{\text {a }}$-receptors.

\section{Materials and methods}

\subsection{Materials}

Eagle's basal medium (with Earle's salts) without inositol was prepared by Serva, all other cell culture media and sera were obtained from Boehringer, Mannheim. Myo- $\left[{ }^{3} \mathrm{H}\right.$ ]inositol (with PT6-271) was from Amersham, Ficoll-Hypaque from Pharmacia. 2-Chloro$\mathrm{N}^{6}-\left[{ }^{3} \mathrm{H}\right]$ cyclopentyladenosine $\left(\left[{ }^{3} \mathrm{H}\right] \mathrm{CCPA}\right)$ was obtained from NEN, 8-cyclopentyl-1,3-[ $\left[{ }^{3} \mathrm{H}\right]$ dipropylxanthine $\left.\left({ }^{3} \mathrm{H}\right] \mathrm{DPCPX}\right)$ from Amersham. All other chemicals were from Sigma.

\subsection{Cell culture}

$\mathrm{GH}_{3}$-cells were a gift from Dr. B. Hamprecht. Physiologisch-Chemisches Institut, Tübingen, F.R.G. They were cultivated in Ham's F 10 medium (Boehringer, Mannheim) containing $2.5 \%$ fetal calf serum and $15 \%$ horse serum (Boehringer) in plastic tissue culture flasks (Falcon or Costar) in a humidified atmosphere $(5 \%$ $\mathrm{CO}_{2}$ ) at $37^{\circ} \mathrm{C}$. The medium was changed two to three times a week, depending on the cell density and the cells were subcultivated every 1-2 weeks. Cells were detached by vigorous pipetting, plated on tissue culture dishes 60 $\mathrm{mm}$ in diameter (Nunc) and grown to a cell density of 1-3 million cells per dish.

Astroblast cultures were prepared by mechanical dissociation of newborn mouse or rat brain and cultivated as described previously (Van Calker et al., 1979).

\subsection{Isolation of neutrophils}

Human neutrophils were isolated from heparinized whole blood obtained from healthy volunteers by means of sedimentation through dextran $(0.6 \% \mathrm{w} / \mathrm{v})$ followed by centrifugation through Ficoll-Hypaque and hypotonic lysis of contaminating erythrocytes (Dougherty et al., 1984; Boyum, 1984).

\subsection{Measurement of inositol phosphate production}

Washed neutrophils were suspended (50 million cells per $\mathrm{ml}$ ) in Eagle's basal medium (with Earle's salts) without inositol containing deoxyribonuclease $(50$ $\mathrm{U} / \mathrm{ml}$ ), fetal calf serum $(3 \%)$ and $50 \mu \mathrm{Ci}\left[{ }^{3} \mathrm{H}\right]$ inositol per $\mathrm{ml}$ and incubated at $37^{\circ} \mathrm{C}$ for $4-5 \mathrm{~h}$ in a shaking water bath. Thereafter cells were centrifuged, and washed two times with ice-cold Hank's balanced salt solution (HBSS) containing $20 \mathrm{mM} \mathrm{N-2-hydroxyethyi-}$ piperazine- $N^{\prime}$-2-ethansulfonic acid (HEPES), pH 7.4. 6 million cells were then incubated with $\mathrm{HBSS}$ at $37^{\circ} \mathrm{C}$ in the presence of cytochalasin B $(5 \mu \mathrm{M}), \mathrm{KCN}(1 \mathrm{mM})$, $\mathrm{LiCl}(10 \mathrm{mM})$ and other additions as required in a final volume of $1 \mathrm{ml}$. Controls received the corresponding amount of vehicle (dimethylsulphoxide, final concentration $0.05 \%)$. The incubations were terminated at the desired times by addition of $1 \mathrm{ml}$ ice-cold trichloroacetic acid $(20 \% \mathrm{w} / \mathrm{v})$. The samples were centrifuged and the pellet was washed once with distilled water. The combined supernatants were extracted with diethylether and fractionated by anion exchange chromatography on small Dowex columns as described previously (Van Calker et al., 1987).

Cultured $\mathrm{GH}_{3}$-cells and astroblasts were labeled with $\left[{ }^{3} \mathrm{H}\right]$ inositol, stimulated with drugs and analyzed for the formation of $\left[{ }^{3} \mathrm{H}\right]$ inositol phosphates essentially as described previously for PC-12 cells (Van Calker et al., 1987).

\subsection{Determination of cyclic AMP}

Dishes containing $\mathrm{GH}_{3}$-cells or astroblasts were washed twice with incubation buffer $(118 \mathrm{mM} \mathrm{NaCl}, 4.7$ $\mathrm{mM} \mathrm{KCl}, 3 \mathrm{mM} \mathrm{CaCl}, 1.2 \mathrm{mM} \mathrm{MgCl}, 1.2 \mathrm{mM} \mathrm{KH}_{2} \mathrm{PO}_{4}$, $0.5 \mathrm{mM}$ EDTA, $10 \mathrm{mM}$ glucose and $20 \mathrm{mM}$ HEPES, $\mathrm{pH} \mathrm{7.4)}$ and thereafter incubated at $37^{\circ} \mathrm{C}$ for $10 \mathrm{~min}$ with $2 \mathrm{ml}$ of the same buffer containing the various additions. Controls received the same amount of vehicle (dimethylsulfoxide, final concentration 0.05\%). The incubations were terminated by removal of the buffer and the addition of $1 \mathrm{ml}$ ice-cold trichloroacetic acid $(10 \%$ $\mathrm{w} / \mathrm{v})$. After removal of the trichloroacetic acid by extraction with diethyl ether ( 3 times $4 \mathrm{ml}$ ), the samples were fractionated by anion chromatography on small Dowex columns (Bio Rad AG $1 \times 2$ ) as described (Van Calker et al., 1979). The cyclic AMP content in the samples was determined by a commercially available protein binding assay (Amersham). 


\subsection{Radioligand binding}

Membranes from whole rat brain and rat striatum were prepared as described previously (Lohse et al., 1987). Binding of $\left[{ }^{3} \mathrm{H}\right] 5^{\prime} N$-ethylcarboxamido-adenosine $\left.\left({ }^{3} \mathrm{H}\right] \mathrm{NECA}\right)(10 \mathrm{nM})$ in the presence of $\mathrm{N}^{6}$-cyclopentyladenosine (CPA) (50 nM) to striatal membranes was performed according to Bruns et al. (1986) with the modifications described earlier (Lohse et al., 1987). Binding assays using $\left[{ }^{3} \mathrm{H}\right] \mathrm{CCPA}$ and $\left[{ }^{3} \mathrm{H}\right] \mathrm{DPCPX}$ were done as described previously (Lohse et al., 1987; Klotz et al., 1989).

\section{Results}

\subsection{Effects of carbamazepine on adenosine $A_{1}$-receptors}

Adenosine inhibits via $A_{1}$-receptors the increase in the accumulation of cyclic AMP, which is evoked in $\mathrm{GH}_{3}$-cells by stimulation with vasoactive intestinal peptide (VIP) (Delahunty et al., 1988) (fig. 1). CBZ (50 $\mu \mathrm{M}$ ) alone slightly reduces the VIP-induced stimulation of the accumulation of cyclic AMP (see legend to fig. i). However, the most prominent effect of CBZ is a parallel shift to the right of the dose-response curve for the inhibitory action of adenosine (fig. 1). Similarly, also the $A_{1}$-receptor-mediated inhibition of the $\beta$-adrenoceptor-induced increased formation of cyclic AMP in cul-

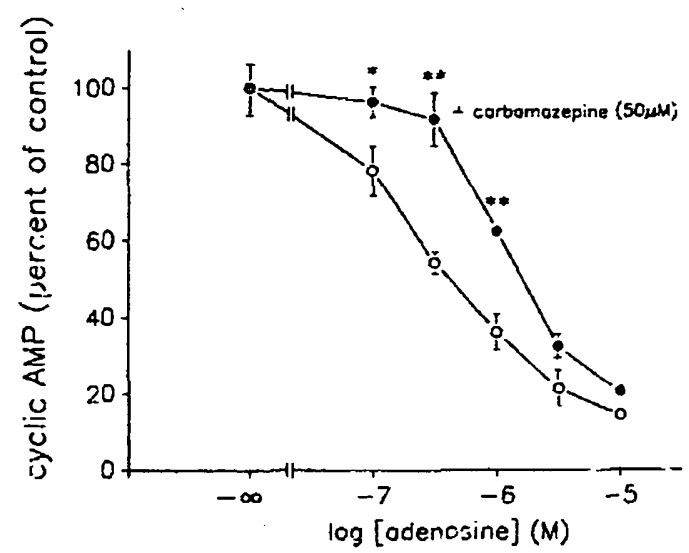

Fig. 1. Influence of carbamazepine $(50 \mu \mathrm{M})$ on the inhibition by adenosine of the VIP-evoked increase in the level of cyclic AMP in $\mathrm{GH}_{3}$-cells. Celts (1.6 million per dish) were incubated for $10 \mathrm{~min}$ in the presence of carbar:azepine or vehicle (dimethylsulfoxide. final concentration $0.05 \%$ ) and the various other additions. The cyclic AMP formed was "ssayed as described in Materials and methods. Controls (pmol cycicic AMP per million cells): basal, 1.0; VIP $(0.1 \mu \mathrm{M}), 101 \pm 8$ $(=100 \%)$; VIP + carbamazepine. $84 \pm 7 \quad(=100 \%)$. Data given are means of triplicate determinations $\pm \mathrm{SD}$. SD's smaller than the size of the symbol are not shown. $* P<0.05,{ }^{*} P<0.01$ (Student's t-test as compared to values without carbamazepine). Similar results were obtained in two additional independent experiments.

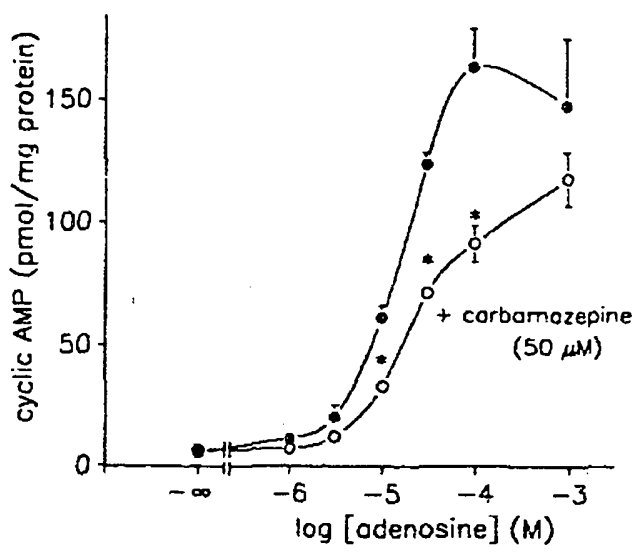

Fig. 2. Influence of carbamazepine $(S 0 \mu \mathrm{M})$ on the increase in the level of cyclic A:MP evoked by adenosine in cultured astroglia cells. Cells were obtained by mechanical dissuciation of newbom rat brain and cultivated for 16 days as described previously (Van Calker $2 t$ al., 1979). They were ther incubated for $10 \mathrm{~min}$ with carbamazepine or vehirle, before the irtracellular content of cyclic AMP was deternined as uescribed in Materials and methods. ${ }^{*} P<0.01$. Other deta'is are as in fig. 1. Similar results were obtained in two additional independent experiments.

tured astroglia cells (Van Calker et al., 1978, 1979) is antagonized by CBZ (data not shown).

\subsection{Effects of carbamazepine on (low'-affinity) adenosine $A_{2 b}$-receptors}

Adenosine and its analogues stimulate via adenosine $\mathrm{A}_{2}$-receptors the accumulation of cyclic AMP in primary

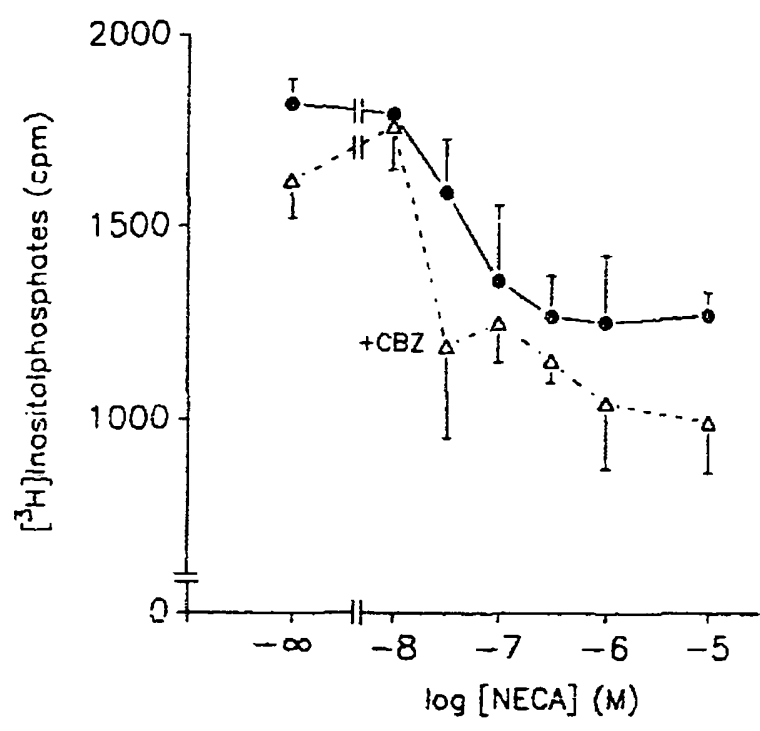

Fig. 3. Influtence of carbamazepine $(50 \mu M)$ on the inhibition by NECA of the FMLP-stimulated increase in the accumulation of inositol phosphates in human neutroshils. Neutrophils were isolated and stimulated with FMLP in the presence of carbamazepine or vehicle and various concentrations of NECA as described in Materials and methods. Similar results were obtained in two additional independent experiments. 
cultures of perinatal rodent brain, mainly consisting of astroglia cells (Van Calker et al., 1979). The low-affinity $A_{2}$-receptors that mediate this effect resemble those which have been called $A_{2 h}$ (Bruns et al., 1987) and are found in virtually all grey matter areas of the brain (Daly et al.. 1983). CBZ attenuates the increase in the level of cyclic AMP evoked by adenosine in the astroglia-rich cultures (fig. 2).

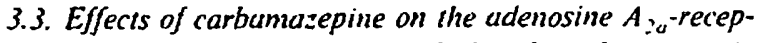
tor-meaiated inhibition of inositol phosphate formation in human neutrophils

In human neutrophils adenosine and its analogues elicit only a minimal increase in the level of cyclic AMP but provoke a pronounced inhibition of the agonist-induced accumulation of inositol phosphates, which is indeperident of cyclic AMP (Van Calker and Steber. submitted). This effect is mediated via high-affinity adenosine $A_{2}$-receptors (Van Calker and Steber, submitted), which resemble those found e.g. in the striatum and called ' $A_{2 a}$ ' (Bruns et al.. 1987). In contrast to its effects on $A_{1}$ - and $A_{2 h}$-receptors, CBZ does not attenuate this effect but induces, if anything, rather a slight potentiation of the inhibition evoked by the adenosine-agonist $5^{\prime}-N$-ethylcarboxamidoadenosine (NECA) (fig. 3).

\subsection{Effects of carbamazepine on the binding of radio- labeled $A_{1}$ - and $A_{2}$-ligands at rat brain membranes}

To further analyze the effects of CBZ at adenosine receptor subtypes we measured its interaction with $A_{1}$ -

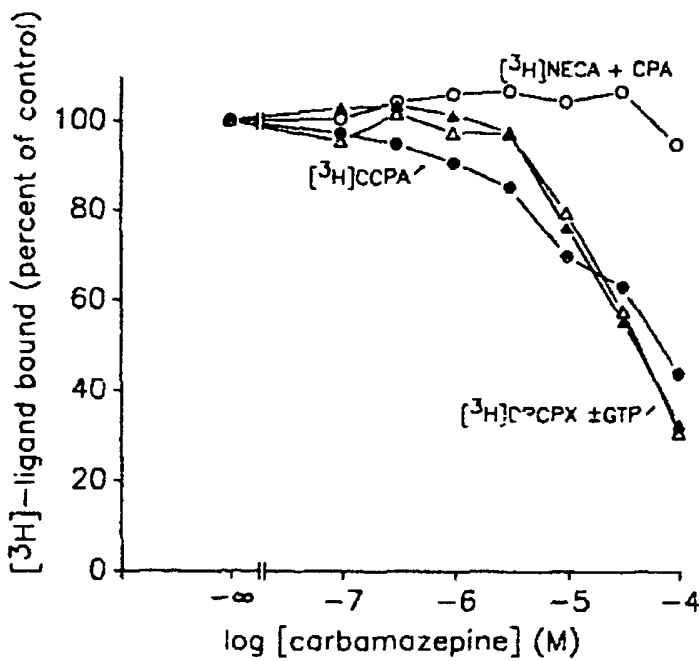

Fig. 4. Iniluence of carbamazepine on the binding of the radioligands $\left[{ }^{3} \mathrm{H}\right] \mathrm{CCPA}$ and $\left[{ }^{3} \mathrm{H}\right] \mathrm{DPCPX}$ to $\mathrm{A}_{1}$-sites in rat brain membranes and of $\left[^{3} \mathrm{H}\right] N E C A$ in the presence of CPA to $A_{2}$-sites in rat striatal membranes. Similar results were obtained in two additional independent experiments. receptors in binding assays with membranes from rat brain performed with the highly $\boldsymbol{A}_{1}$-selective radioligands 2-chloro- $N^{6}-\left[{ }^{3} \mathrm{H}\right]$ cyclopentyladenosine ([ $\left.{ }^{3} \mathrm{H}\right] \mathrm{CCPA}$, an agonist) (Klotz et al., 1989) and 8cyclopentyl-1,3-[ $\left.{ }^{3} \mathrm{H}\right]$ dipropylxanthine $\left(\left[{ }^{3} \mathrm{H}\right] \mathrm{DPCPX}\right.$, an antagonist) (Lohse et al., 1987). The action of CBZ at high affinity $\mathrm{A}_{2, \mathrm{~s}}$-receptors was evaluated with membranes from ral striatum, using $\left[{ }^{3} \mathrm{H}\right] \mathrm{NECA}$ as a radioligand in the presence of $N^{6}$-cyclopentyladenosine (CPA) to block the binding to $A_{1}$-sites (Bruns et al., 1986). CBZ inhibited the binding of both $\left[{ }^{3} \mathrm{H}\right] \mathrm{CCPA}$ and $\left[{ }^{3} \mathrm{H}\right] \mathrm{DPCPX}$ to rat brain membranes (fig. 4). The displacement by CBZ of $\left[{ }^{3} \mathrm{H}\right] \mathrm{DPCPX}$-binding was not influenced by the presence of $100 \mu \mathrm{M}$ GTP. In contrast, CBZ did not affect at concentrations below $100 \mu \mathrm{M}$ the binding of $\left[{ }^{3} \mathrm{H}\right] \mathrm{NECA}$ to striatal membranes (fig. 4).

\section{Discussion}

The inhibitory effects of CBZ on adenosine-evoked second-messenger responses that are reported in the present study provide the first direct evidence that $\mathrm{CBZ}$ inhibits second messenger-responses mediated by adenosine $A_{1}$-receptors but not those mediated by high-affinity $A_{2 a}$-receptors. $C B Z$ induces a parallel shift to the right of the dose-response curve for the $A_{1}$-induced inhibition of the VIP-stimulated cyclic AMP accumulation in $\mathrm{GH}_{3}$-cells (fig. 1), as expected for a competitive interaction. In contrast, the $\mathbf{A}_{2 \mathrm{a}}$-mediated inhibition of the IMLP-stimulated formation of inositol phosphates in human ntutrophils is not antagonized by CBZ (fig. 3).

In addition to its antagonistic effect at $A_{1}$-receptors $\mathrm{CBZ}$ also inhibits the $\mathrm{A}_{2 \mathrm{~b}}$-receptor-mediated increase in cyclic AMP in cultured astroglia cells (fig. 2). Similarly, $\mathrm{CBZ}$ at high concentrations also attenuates the adenosine-evoked increase in the level of cyclic AMP in brain slices (Lewin and Bleck, 1977; Skenitt et al., 1983a; Weir et al., 1984), which is probably also mediated by low-affinity $A_{2 b}$-receptors (Daly et al., 1983). These effects may be at least partially due to $a$ ? antagonism of $\mathrm{CBZ}$ also at $\mathrm{A}_{2 \mathrm{~b}}$-receptors. However, the dose-response curve depicted in fig. 2 is not typical for a competitive interaction of $\mathrm{CBZ}$ with $\mathrm{A}_{2 \mathrm{~b}}$-receptors. Furthermore, by mechanisms other than competitive inhibition, $\mathrm{CBZ}$ also weakly attenuates the increase in the level of cyclic AMP evoked by the activation of putative $A_{2 a}$-receptors in PCl2 cells and platelets (Daly et al., 1988). Thus, mechanisms other than competitive inhibition could also account for the inhibition by CBZ of cyclic AMP accumulation in various tissues and cell types. A more detailed analysis of the mechanism of CBZ's inhibition of the adenosine-induced increase in cyclic AMP in astroblasts is hampered by the low affinity of the $\mathrm{A}_{2 \mathrm{~b}}$ receptors. 
A selective interaction of $\mathrm{CBZ}$ with $\mathrm{A}_{1}$-, but not $A_{2 \mathrm{a}}$-receptors was further supported by binding studies using $\left[{ }^{3} \mathrm{H}\right] \mathrm{CCPA}$ and $\left[{ }^{3} \mathrm{H}\right] \mathrm{DPCPX}$ as highly selective $A_{1}$-radioligands and $\left[{ }^{3} \mathrm{H}\right] N E C A$ in the presence of CPA as $\mathrm{A}_{2 \mathrm{a}}$-radioligand (fig. 4). While the present work was in progress, similar conclusions have been drawn from binding studies performed with $N^{6}$-cyclohexyl$\left[{ }^{3} \mathrm{H}\right]$ adenosine and $\left[{ }^{3} \mathrm{H}\right] \mathrm{NECA}$ (Clark and Post, 1989).

CBZ's selective antagonism at $A_{1}$-receptors may explain why its profile of clinical and behavioral effects is different from that of non-selective adenosineantagonists like theophylline and caffeine. Indeed, 8cyclopentyltheophylline (CPT), which acts as a selective $A_{1}$-antagonist in vivo, does not have the stimulating effect on locomotor activity which occurs with theophylline. On the other hand, CPT has proconvulsant properties in animal models (for review see Bridges et al., 1988). Thus, CBZ's $A_{1}$-antagonistic properties are probably not involved in its anticonvulsant action, as already concluded from other evidence (Post, 1987).

Although apparently not involved in its anticuniuisive effects, the blockade of $A_{1}$-receptors by $C B Z$ might be related to its efficacy as a prophylactic, antimanic and possibly also antidepressive agent in affective psychoses. Several $A_{1}$-antagonists show antidepressantlike activities in animal models (see Bridge: et al., 1988 for review). In addition, effestive antidep; essive treatments like electroconvulsive shock (Newma- et al., 1984; Gleiter et al., 1989) and REM sleep deprivation (Yanik and Radulovacki, 198\%) !!p-regulate $A_{1}$-receptors, similar to chronic treatment with CBZ (Marangos et al., 1985, 1987b; Daval et al., 1989).

Some of CBZ's complex effects on various neurotransmitter systems seen in behavioral and biochemical studies (for review see Elphick, 1988; Post, 1987, 1990) could be indirectly mediated by the $A_{1}$-antagonistic action of CBZ, since the release of many excitatory and inhibitory neurotransmitters is inhibited by adenosine via $A_{1}$-receptors (for review see Bridges et al., 1988).

The use of $\mathrm{CBZ}$ as an :Iternative to lithium in the treatment of manic-depressive illness raises the question of whether or not there are also similarities in the biochemical effects of both drugs. The inhibitory effects of chronic lithium treatment on the agonist-stimulated increase in the accumulation of cyclic AMP (Belmaker, 1981; Ebstein et al., 1988) and inositol phosphates (Casebolt and Jope, 1989; Ebstein et al., 1988; Elphick et al., 1988; Godfrey et ai., 1989; Kendall and Nahorski, 1987) may be involved in lithium's antimanic and prophylactic properties. $C B Z$ inhibits the accumulation of cyclic AMP in brain slices stimulaied by noradrenaline, ouabain and adenosine (Lewin and Bleck, 1977; Palmer et al., 1979; Skerritt et al., 1983a; Weir et al., 1984), although only at high concentrations. CBZ's effects on the agonist-evoked formation of inositol phos- phates are controversial (Elphick et al., 1988: McDermott and Logan, 1989).

In addition to these possible direct effects on second messenger generation, CBZ might also interfere with the potent synergistic interactions of adenosine with various neurotransmitters in the regulation of both cyclic AMP and inositol phosphate formation (El-Etr et al., 1989; Hill and Kendall, 1987; Hollingsworth et al., 1986). The blockade by CBZ of $A_{1}$ - and possibly also $A_{2 b}$-receptors should inhibit these synergistic effects of adenosine and could thereby profoundly alter the regulation by various neurotransmitters of both second messenger systems. Thus, lithium ions and carbamazepine might, via different mechanisms, both elicit a dampening effect on second messenger generation that could be important for their similar profile of clinical efficacy in affective psychoses.

\section{Acknowledgements}

The authors are indebted to Drs. H. Thoenen and R. Heumann (Max Planck Institute for Psychiatry. Martinsried. F.R.G.) for the opportunity to use their cell culture facilities, to Dr. B. Hamprecht for a gift of $\mathrm{GH}_{3}$-cells and to Mrs. Annette Schröder for expert technical assistance. This work was supported by the Deutsche Forschungsgemeinschaft ( $\mathrm{Gr} 460 / 4-2)$.

\section{References}

Belmaker, R.H. 1981. Receptors, adenylate cyclase and lithium, Biol. Psychiat. 16, 333.

Boyum. A.. 1984, Separation of lymphocytes. granulocytes, and monocytes from human blood using iodinated density gradient media. Meth. Enzymol. 108, 88.

Bridges. A.J.. R.F. Bruns and T.G. Heffner. 1988. Central nervous system actions of adenosine agonists and antagenistis, in: Annual reports in medicina! chemistry. Vol. 23. ed. M. Berger (Academic Press. New York) p. 39

Brins, R.F.. G.H. Lu and T.A. Pugsley. 1986. Characterization of the $A_{2}$ adenosine receptor labeled by $\left.l^{3} \mathrm{H}\right] \mathrm{NECA}$ in $i$ at strialal membranes. Mol. Pharmacol 331, 346.

Bruns. R.F.. G.H. Lu and T.A. Pugsley. 1987. Adenosine receptor subtypes: binding studies. in: Topics and Perspectives in Adenosine Research, eds. E. Gerlach and B.F. Becker (Springer, Berlin) p. 59.

Casebolt. T.L. and R.S. Jope, 1989. Long-term lithium treatment selectively reduces receptor-coupled inositol phospholipid hydrolysis in rat brain. Biol. Psychiat. 25, 329.

Catterall. W.A., 1987, Comnion modes of drug action on $\mathrm{Na}^{+}$channels : local anesthetics, antiarrhythmics and anticonvulsants, Trends Pharmacol. Sci. 8, 57.

Clark, M. and R.M. Post, 1989, Carbamazepine, but not caffeine, is highly selective for adenosine $A_{1}$, binding sites. Eur. J. Pharmacol. 164, 399.

Daly. J.W.. P. Butts-Lamb and W. Padgett, 1983, Subclasses of adenosine receptors in the central nervous system: interaction with caffeine and related methylxanthines. Cell. Moi. Neurobiol. 3.69.

Daly, J.W.. O. Hong. W.L. Padgett. M.T. Shamim. K.A. Jacobson and 
D. Ukena, 1988, Non-xanthine heterocycles: activity as antagonists of $A_{1}$ - and $A_{2}$-adenosine receptors. Biochem. Pharmacol. 37. 655

Daval, J-L. J. Deckert, S.R.B. Weiss, R.M. Post and P.J. Marangos, 1989. Upregulation of adenosine $A_{1}$-receptors and forskolin hinding sites following chronic treatment with caffeine or carbamazepine: a quantitative autoradiographic study. Epilepsia 30. 26.

Delahunty. T.M.. M.J. Cronin and J. Linden, 1988. Regulation of $\mathrm{GH}_{3}$-cell function via adenosine $\mathrm{A}_{1}$-receptors, Biochem. J. 255.69

Dougherty. R.W., P.P. Godfrey, P.C. Hoyle. J.W. Putney and R.J. Freer, 1984, Secretagogue-induced phosphoinositide metabolism in human leucocytes. Biochem. J. 222. 307.

Ebstein. R.P., B. Lerer, ER. Bennet. B. Shapira. S. Kindler. Z. Shemesh and N. Gerstenhaber, 1988. Lithium nodulation of second messenger signal amplification in man: inhibition of pl.s.phatidyl-inositol-specific phospholipase $\mathrm{C}$ and adeny!a.e cyclase activity, Pswchiatry Res. 24, 45.

El-Etr, M., J. Cordier, J. Glowinski and J. Premont. 1989. A neuroglial conperativity is requirt-l for the potentiation by 2-chloroadenosine of the muscannic-sensitive phuspholipase $C$ in the striatum, J. Neurosci. 9. 1473.

Elphick, M., 1988. The clinical uses and phamacology of carbamazepine in psychiatry. Int. Clin. Psychopharmacol. 3. 185.

Elphick. M., Z. Taghavi, T. Powell and P.P. Godfrey, 1988, Alteration of inositol phospholipid metabolisn in rat cortex by lithium but not carbamazepine, Eur. J. Pharmacol. 156, 411.

Fujiwara, Y.. M. Sato and S. Otsuki, 1986, Interaction of carbamazepine and other drugs with adenosine $\left(A_{1}\right.$ and $\left.A_{2}\right)$ receptors. Psychopharmacology 90, 332.

Gasser, T., M. Reddington and P. Schubert, 1988. Effect of carbamazepine on stimulus-evoked $\mathrm{Ca}^{2+}$-fluxes in rat hippocampal slices and its interaction with $A_{1}$-adenosine receptors, Neus osci. Lett. 91, 189.

Gleiter, C.H., J. Deckert. D.J. Nutt and P.J. Marangos. 1989, Electroconvulsive shock (ECS) and the adenosine neurommdulatory sys. tem: effect of single and repeated ECS on the adenosine $A_{1}$ and $A_{2}$ receptors, adenylate cyclase, and the adenosine uptake site, $J$. Neurochem. 52.641

Godfrey, P.P.. S.J. McClue, A.M. White, A.J. Wood and D.C. Grahame-Smith, 1989, Subacute and chronic in vivo lithium treatment inhibits agonist- and sodium nuoride-stimulated inositol phosphate production in rat cortex, J. Neurochem. 52, 498.

Hamprecht, B. and D. Van Calker. 1985, Nomehclature of adenosine receptors. Trends Pharmacol. Sci. 7. 153.

Hill, S.J. and D.A. Kendall, 1987, Studies on the adenosine-receptor mediating the augmentation of histamine-induced inositul phospholipid hydrolysis in guinea-pig cerebral cortex, Br. J. Pharmacol. 91,661

Hollingsworth, E.B., R. De La Cruz and J.W. Daly, 1986, Accumulation of inositol phosphates and cyclic AMP in brain slices; synerg istic interactions of histamine and 2-chloroadenosine, Eur. J. Pharmacol. 122, 45.

Kendall, D.A. and S.R. Nahorski, 1987, Acute and chronic lithium treatment influence agonist and depolarisation-st:melated inositol phospholipid hydrolysis in rat cerebral cortex. J. Pharmacol. Exp. Ther. 241, 1023.

Klotz, K.-N., M.J. Lohse, U. Schwabe, G. Cristalli, S. Vittori and

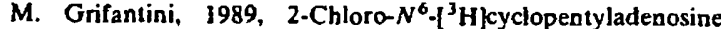
$\left({ }^{3} \mathrm{H}\right] \mathrm{CCPA}$ - a high affinity agonist radioligand for $A_{1}$ adenosine receptors. Naunyn-Schmjedeberg's Arch. Pharmacol. 340, 679.

Lewin, E. and V. Bleck, 1977, Cyclic AMP accumulation in cerebral cortical slices: effect of carbamazepine. phenobarbital. and phenytoin, Epilepsia 18, 237.

Lohse, M.J., K.-N. KJotz J. Lindenborn-Fotinos, M. Reddington, U.
Schw'abe and R.A. Olsson, 1987, 8-cyclopentyi-1,3-dipropylxanthin (DPCPX) - a selective high affinity antagonist radioligand for $\mathrm{A}_{2}$ adenosine receptors, Naunyn-Schmiedeberg's Arch. Pliarmacol. 336, 204.

Londos, C., D.M. Cooper and J. Wolff. 1980, Subclasses of external adenosine receptors, Proc. Natl. Acad. Sci. U.S.A. 77, 2551.

Marangos. P.J., J. Deckert and J.-C. Bisserbe, 1987a, Central sites of adenosine action and their interaction with various drugs, in: Topics and Perspectives in Adenosine Research. eds. E. Gerlach and B.F. Becker (Springer. Berlin) p. 74.

Marangos, P.J., P. Montgomery, S.R.B. Weiss, J. Patel and R.M. Post. 1987b. Persistent upregulation of brain adenosine receptors in response to chronic carbamazepine treatment, Clin. Neuropharmacol. 5. 443.

Marang.s. P.J., J. Patel, K.D. Smith and R.M. Post, 1987c, Adenosine antagonis, properties of carbamazepine, Epilepsia 2\%, 387.

Marangos. P.J., S.R.B. Weiss, P. Montgomery. J. Patel, P.K. Narang. A.M. Cappabianca and R.M. Post, 1985, Chronic carbamazepine treatment increases brain adenosine receptors, Epilepsia 26, 493.

McDermott, E.E. and S.D. Logan. 1989. Inhibition of agonist-stimulated inositol tipid metabolism by the anticonvulsant carbamazepine in rat hippocampus, Br. J. Pharmacol, 98, 59:

Newman, M.. J. Zohar, M. Kalian and R.H. Belmaker, 1984. The effects -? chronic lithium and ECT on $A_{1}$ and $A_{2}$ adenosine receptors in rat brain. Brain Res. 291, 188.

Palmer, Ci.C., Jones. D.J.. Medina. M.A. and W.B. Stavinoha, 1979, Anticonvulsant drug actions on in vitro and in vivo levels of cyclic AMP in the mouse brain, Epilepsia 20, 95.

Phillis. J.W., 1984. Interactions of the anticonvulsants diphenylhydantoir, $^{3}$ and carbamazepine with adenosine on cerebral cortical nesia $\cdot 15$, Epilepsia 25, 765.

Post. M., 1987, Mechanism of action of carbamazepine and related anticonvulsants in affective illness, in: Psychopharmacology: The Third Generation of Progress, ed. H.Y. Meltzer (Raven Press, New York) p. 567.

Post, R.M., 1990, Sensitization and kindling perspectives for the course of affective illness: toward a new treatment with the anticonvulsant carbamazepine, Pharmacopsychiatry 23, 3.

Schmidt, S. and W. Greil, 1987, Carbamazepin in der Behandlung psychiatrischer Erkrankungen, Nervenarzt 58, 719.

Skerrith J.H.. L.P. Davies and G.A.R. Johnston, 1983a, Interaction or the anticconvulsant carbamazepine with adenosine receptors. 1. Nenrochemical studies, Epilepsia 24, 634.

Skerrith, J.H., C.A.R. Johnston and S. Chen Chow, 1983b, Interactions of the anticonvitisant carbamazepine with adenosine receptors. 2. Pharmacological studies, Epilepsia 24, 643.

Van Calker, D., K. Assmann and W. Greil, 198?, Stimulation by bradykinin. angioiensin $\mathrm{H}$, and carbachoi of the accumulation of inositol phosphates in PC-12 pheochromocytoma cells: differential effects of lithium ions on inositol mono- and polyphosphates, J. Neurochem. 49. 1379.

Van Calker, D., M. Muller and B. Hamprechı, 1978. Adenosine inhibits the accumulation of cyclic AMP in cultured brain cells. Nature 30, 713.

Van Calker, D., M. Müller and B. Hamprecht, 1979. Adenosine regulates via two different types of receptors the accumulation of cyclic AMP in cultured brain cells, 3. Neurochem. 33, 999.

Weir, R.L.. W. Padgett, J.W. Daly and S.M. Anderson, 1984, Interaction of anticonvulsant drugs with adenosine receptors in the central nervous system. Epilepsia 25. 492.

Yanik, G. and M. Radulovacki, 1987, REM sleep deprivation up-regulates adenosine A, receptors, Brain Res. 402. 362. 